\title{
The Autonomy of Indonesian EFL Students: A Mixed Method Investigation
}

\author{
M. Melvina, Nenden Sri Lengkanawati and Yanty Wirza \\ Universitas Pendidikan Indonesia, Bandung, Indonesia \\ https:/ / orcid.org/0000-0002-3687-2295 \\ https:// orcid.org/0000-0002-9903-6198 \\ https://orcid.org/0000-0001-9417-9686
}

\begin{abstract}
The present study sought to scrutinize undergraduate EFL students' learning autonomy in a state university in Indonesia. This study employed a triangulation study of mixed-method design by distributing questionnaires and conducting interviews to get quantitative and qualitative data. The questionnaire was distributed to 40 second year participants enrolled in listening, speaking, reading, and writing for academic purposes classes, whereas 15 participants were selected for the interview Descriptive statistics and thematic analysis were used to analyse the data collected from the questionnaire and the interview. Findings revealed that the level of students' learner autonomy was classified as moderate level of autonomy. This indicated that Indonesian undergraduate students were considered somewhat autonomous learners. In addition, the Indonesian undergraduate students defined learner autonomy as independent learning with or without the teacher's assistance, students responsible for their own learning, and learner autonomy was the student's self-awareness and self-initiated to learn outside the classroom to find ways of learning and collaborate with others. The study recommended that teachers should consistently develop learner autonomy in their teaching practice.
\end{abstract}

Keywords: autonomy behaviour; autonomy levels; motivation; undergraduate students

\section{Introduction}

The industrial revolution has brought changes in implementing education (Gleason, 2018). In response to the demands of the Industry 4.0 era, teaching methods need to be adapted to the changing nature of learning (Suherdi, 2019). This makes teachers tend to serve as mentors or facilitators instead of educators. Specifically, Education 4.0 requires teachers and students to utilize more digital technology tools in language learning. Considering the requirement of the Education 4.0, language learners are required to be active and independent in 
learning due to plenty of information and resources for learning that can be obtained from the internet. They can discuss or solve their learning problems through social media or online messages. Moreover, they do not have to be dependent on their teachers in learning. This emphasizes that language learners need to take the responsibilities for deciding the aspect of learning, the capacity to take control of their learning, the ability and willingness to take responsibility for their learning, and work together with teachers and other learners to achieve shared goals (Benson \& Voller, 2014).

In this connection, learner autonomy is highly needed to prepare learners to be independent and to exercise control over their own learning. Learner autonomy is considered an important notion in language learning and research and a desirable goal in the teaching and learning of second and foreign languages (Benson, 2013). Learner autonomy leads the learner to learn independently, take responsibility for their own learning, and help learners to be effective in learning(Borg \& Alshumaimeri, 2019; Hsu et al., 2019). It can be said that autonomous language learners know how and when to learn or have learning management skills. Therefore, they can learn effectively and efficiently. In addition, learner autonomy prepares learners for lifelong learning (Mynard, 2019). In this case, autonomous learners have autonomy skills to help them fulfil the demand of education 4.0 after graduating from university.

Despite many empirical studies that have been conducted in terms of learner autonomy in ESL and EFL context by many researchers (Abdel Razeq, 2014; Alrabai, 2017; Borg \& Alshumaimeri, 2019; Kobayashi, 2020; Lin \& Reinders, 2019; Sönmez, 2016; Tayjasanant \& Suraratdecha, 2016), the topic of learner autonomy is still a new research area in Indonesia. In Indonesian EFL context, learner autonomy has been introduced by some experts and researchers. The majority of the studies had focused on teachers' beliefs and practices in developing learner autonomy(Agustina, 2017; Lengkanawati, 2017; Meisani \& Rambet, 2017; Melvina \& Suherdi, 2019), teachers' and students' perception and practices towards autonomous learning (Khotimah et al., 2019; Ramadhiyah \& Lengkanawati, 2019), autonomous learning activities (Khulaifiyah et al., 2021),learner autonomy and gender (Mardjuki, 2018), learner autonomy and digital literacy (Andina et al., 2020; Muhammad, 2020), learner autonomy and language proficiency (Melvina \& Julia, 2021; Myartawan et al., 2013), students' readiness of learner autonomy (Cirocki et al., 2019; Fauzi et al., 2020). However, the theme focusing on the level of learner autonomy is still rare. Therefore, this study aimed to investigate the level of autonomy of the students, because knowing their level of autonomy helps teachers better plan their teaching to promote the learners to become autonomous. The 2013 curriculum requested teachers to promote learner autonomy, particularly in the higher education level.

Specifically, this study is carried out to investigate the level of undergraduate students' autonomy in learning English based on the four aspects of learner autonomy (technical, psychological, political-philosophical, and sociocultural dimensions) that have been re-conceptualized by Murase (2015) from the 
already existing theory (Benson, 1997; Oxford, 2003), and how they understand the definition of learner autonomy.

\section{Theoretical Framework}

\subsection{The Dimension of Learner Autonomy}

Learner autonomy is classified by Benson (1997) into technical, psychological, and political dimensions. Oxford (2003) has the social culture dimension. Then, Murase (2015) tried to re-conceptualize the construct to measure learner autonomy based on the version of autonomy of Benson (1997) and Oxford (2003). These four dimensions were used as a conceptual framework of this study.

\subsubsection{Technical Dimension}

Technical autonomy is defined as students learning a language on their own, out of the classroom, and without the help of a teacher. It is also defined as a situation where students must control their own learning (Benson, 1997). It relates to the skills that they need to learn autonomously. Technical autonomy consists of behavioral and situational sub-dimensions. Behavioral autonomy is related to the learners' capacity utilizing a number of learning strategies or tactics for taking control of their learning, such as setting goals, selecting learning materials and activities, planning, checking learning progress, and assessing or evaluating the learning progress (Cotterall, 1995b). Those are all frequently labeled as metacognitive strategies (Wenden, 1998). Then, situational autonomy is described as 'situations in which learners are obliged to take charge of their own learning' (Benson, 1997, p19).

\subsubsection{Psychological Dimension}

Psychological autonomy relates to individual learners' capacity that enables learners to take more responsibility for their own learning" (Benson, 1997, p. 19). Psychological autonomy is divided into three sub-dimensions: metacognitive, motivational, and affective (Murase, 2015). The metacognitive sub-dimension refers to metacognitive knowledge that supports students' capability to practice metacognitive strategies effectually. The motivational sub-dimension includes learner desires, responsibility, willingness, and feel of agency (Breen \& Mann, 1997; Little, 1990; Oxford, 2003) As far as the third sub-dimension is concerned, anxiety, self-esteem, and emotions are the affective factors that arise from individual learners.

\subsubsection{Political-philosophical Dimension}

Political-philosophical autonomy consists of group and individual autonomy (Murase, 2015). Group autonomy is a perspective of awareness of the teacher as the authority and the parents or government policy as other kinds of authorities. Individual autonomy is the ability of the learners to make decisions about some aspects of learning, such as content, goals, and objectives in learning English. In addition, the political-philosophical dimension is associated with the idea of freedom to learn. Negative freedom is defined as where students have the freedom to study based on their preferences. Positive freedom is a situation where students can control their learning freely with the approval and 
cooperation of teachers or other authorities. Therefore, it is suggested to provide learners freedom in determining the learning content (Benson, 2013).

\subsubsection{Socio-cultural Dimension}

Socio-cultural autonomy has two main sub-dimensions, namely socialinteractive and cultural. The social-interactive sub-dimension is influenced by Vygotsky's sociocultural theory (Murase, 2015). Social interaction plays important role developing learner autonomy. Through social interaction with other people, such as teachers and their friends, students develop their autonomy in language learning. The cultural sub-dimension focuses more on the social aspects of learner autonomy, also known as national or ethnic culture (Palfreyman, 2003).

\subsection{Autonomous Language Learners}

Autonomous language learners are considered efficient because they have the important skill to manage their learning (Benson, 2011). In addition, autonomous learners are active and critical to think about what knowledge they need. They apply effective learning strategies and check the progress of their own learning (Benson, 1997; Lengkanawati, 2017; Nunan, 2003; Oxford, 2008).In addition, Little and Dam (1998) asserted that autonomous learners are successful learners because they have intrinsic motivation. This intrinsic motivation encourages them to accept responsibility for their own learning and commit to developing self-reflective management skills in learning. Little and Dam (1998) further emphasized that autonomous learners are motivated and reflective learners. Therefore, their learning becomes effective and efficient. Also, they could practice knowledge and skills in independent learning outside the classroom.

According to Cotterall (1995a), autonomous learners can evaluate the quality of their learning, and appreciate their abilities, progress, and accomplishment. Besides, they can solve the obstacles that may arise from educational backgrounds, cultural norms, and previous experiences. Meanwhile, Dickinson (1993) proposed that autonomous learners can collaborate with the teacher to create their own learning goals.

\subsection{The Level of Learner Autonomy}

The degree of learner autonomy can be seen from a lower to a higher level (Benson, 2011). Learners with a high level of autonomy can control their learning activity as well as determine its directions. Meanwhile, learners with a low level of autonomy can only perform some specific activities of learner autonomy. Littlewood (1996) elucidated three levels of autonomy. At the communicative level, students can make choices about the practice of language and appropriate strategies when communicating in certain situations and tasks. At the level of learning, students are expected to be able to use appropriate learning strategies independently. At the personal level, students can make choices about their language learning in a wider context. Then, in 1999, Littlewood introduced proactive and reactive autonomy. Proactive autonomy shows that students have full autonomy, while reactive autonomy denotes that students work after receiving learning directions from the teachers. 


\section{Methods}

\subsection{Research Design}

This research was completed using a mixed-methods approach by combining quantitative and qualitative research. In this research, a triangulation or convergent study of mixed methods design was opted to gather different data (Creswell \& Clark, 2017).To collect data, there are two stages (see figure.1). The first stage is to collect quantitative data by distributing questionnaires to the participants. Then, the second stage is to obtain qualitative data through a semistructured interview. Data gained from the questionnaires and interviews were analysed separately. The results of the qualitative analysis were used to triangulate the quantitative findings.

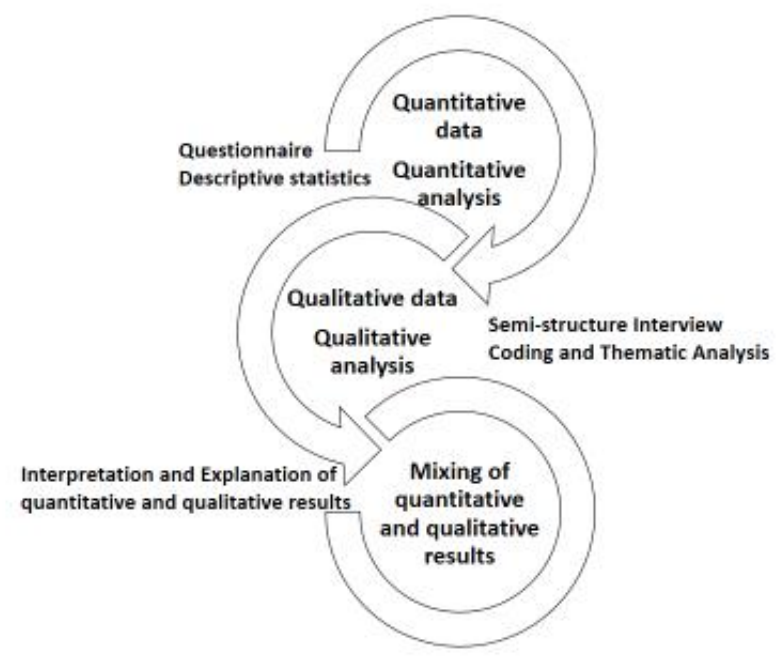

Figure 1: Flowchart of the research

\subsection{Participants}

There were 40 undergraduate students of one state university in Indonesia involved in this research as the participants. They were enrolled in semester four the English education program. The fourth-semester students were selected as the participants because they had already taken the prerequisite course and practiced some student-cantered learning approach. To select the participants of the study, the researchers used the convenience sampling technique. It is a type of non-probability sampling where subjects of the research meet certain practical criteria. For example, easy accessibility, geographical proximity, availability at a given time, or the willingness to participate in the study (Dörnyei, 2007). The selected participants consisted of 12 male students $(30 \%)$ and 28 female students (70\%). Their age ranged from 18 to 20 years old.

\subsection{Research Instruments}

Two instruments were used to collect the data. The first was a questionnaire, Measuring Instrument for Language Learner Autonomy (MILLA), adapted from Murase (2015) to collect quantitative data. MILLA comprises of four dimensions of learner autonomy: technical, psychological, political-philosophical, and sociocultural dimensions. After consulting a professor who is an expert in 
learner autonomy, several items that were not closely related to the Indonesian context were omitted. The questionnaire was then translated into the Indonesian language. The four-point Likert Scale questionnaire consisted of 87 items, and was splitted into four dimensions of learner autonomy. Cronbach's alpha was measured to determine the reliability of the questionnaire. The results confirmed that the overall items have high degree of reliability with the value of 0.98 . The value $\geq 0.8$ signifies that the items have good internal consistency (Vaske et al., 2017). The second instrument was a semi-structured interview. 15 students were selected purposively for an interview after the questionnaire analysis. Four follow-up questions were adopted from Le Thanh Nguyet (2019) to explore students' knowledge regarding learner autonomy, students' level of autonomy, and students' autonomy behaviour.

\subsection{Procedures}

The questionnaire was distributed after getting the participant's consent by signing the consent form. The participants completed the questionnaire in a week. Furthermore, after analysing the questionnaire results, a follow-up interview was carried out. The researchers made appointment to the students before interviewed.

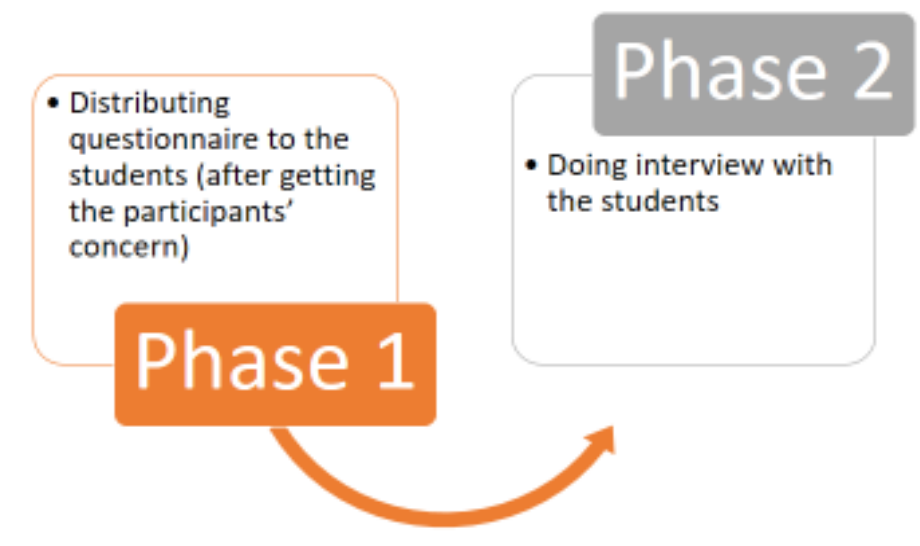

Figure 2: Research procedure

\subsection{Data Analysis}

Descriptive statistics, such as frequencies, percentages, and index scores, were conducted to analyse students' degree of learner autonomy. The degree of students' autonomy was categorized into three. The index score above 80 indicates a high level of learner autonomy, the index score between 60 and 80 indicates a mediate level of learner autonomy, and the index score below 60 indicates a low level of learner autonomy (Elizondo \& Garita, 2013). Furthermore, thematic analysis was used to analyse the data collected through the interview. 


\section{Results}

\subsection{Quantitative Findings}

Undergraduate students level of autonomy in English language learning

In this study, learners' level of autonomy was based on four dimensions of learner autonomy consisting of technical dimension, psychological dimension, political-philosophical dimension, and sociocultural dimension. The results of the quantitative analysis showed that undergraduate students' overall degree of autonomy was categorized in the mediate level of learner autonomy with an index score of $74 \%$. This indicated that Indonesian undergraduate students were considered autonomous learners. They had implemented some behaviours of learner autonomy.

Table 1: Students' overall degree of learner autonomy

\begin{tabular}{lll} 
Dimensions of Learner Autonomy & $\begin{array}{l}\text { Index Score } \\
\text { Technical }\end{array}$ & $\begin{array}{l}\text { Category } \\
\text { Mediate-level }\end{array}$ \\
Psychological & $81 \%$ & High-level \\
Political-Philosophical & $71 \%$ & Mediate-level \\
Sociocultural & $76 \%$ & Mediate-level \\
$\begin{array}{l}\text { Students' overall degree of learner } \\
\text { autonomy }\end{array}$ & $74 \%$ & Mediate-level \\
\hline
\end{tabular}

Table 1 above shows that the technical dimension had an index score of $66 \%$, indicating that it was in a mediate level of learner autonomy, whereas psychological dimension had an index score of $81 \%$, indicating that it was in a high level of learner autonomy. The political-philosophical dimension and sociocultural dimension had an index score of $71 \%$ and $76 \%$, respectively, indicating that they were both in a mediate level of learner autonomy. These results concluded that the psychological dimension had the highest index score and the technical dimension had the lowest index score.

\subsubsection{Technical Dimension}

The findings in the technical dimension confirmed that most students could set learning goals and make a study plan. In setting long-term goals in learning English, $45 \%$ of students answered often. Similarly, $45 \%$ of students answered frequently in making long-term plans to learn English. Half of the students (50\%) frequently made realistic plans for studying English. However, they rarely assessed their learning goals and study plans. Interestingly, they often evaluated the improvement of their English ability. Besides, they rarely reflected on their studies, but they frequently reflected on their learning after finishing studying English. The students also reported that they were able to create favourable times to practice English outside the classroom and manage their learning in the situation where they self-study. Half of the students confirmed that they could study English without teachers in the library or on the internet. However, they rarely attended a self-study centre to develop their English skills and joined an English club where they were allowed to practice English. 


\subsubsection{Psychological Dimension}

The findings in the psychological dimension confirmed that the undergraduate students could control their learning autonomously. They had a high motivation in learning English, knew how to motivate themselves, and were responsible for their best achievement in learning English. For instance, the majority of the students (85\%) aspired to continue their studies abroad after graduation; $65 \%$ of them aspired to work overseas in the future; $62.5 \%$ of them liked the English language. Meanwhile, 50\% of the students liked studying English; 37.5\% of them gave the highest priority to learning English over studying other academic subjects. In addition, $70 \%$ of students viewed that English language skills can help them get a better job.

Furthermore, the findings showed that undergraduate students could use metacognitive strategies effectively. For example, most of them concurred that they should set their learning goals $(70 \%)$, create a long-term plan for learning English $(62.5 \%)$, choose materials that are appropriate to their learning goals $(62.5 \%)$, make a study plan that meets their learning goals (65\%) and make a realistic plan for learning English (50\%). Half of the students strongly agreed that students must create conditions so that they can learn English well (55\%). More than half of the participants (67.5\%) agreed that they should evaluate their ability to use English effectively. The majority of participants $(72.5 \%)$ agreed that the effectiveness of their English study plan should be assessed.

In this study, the students agreed that they recognized their learning needs to improve their English (47.65\%); a half of the students (57.5\%) agreed that they were good at learning English; $60.0 \%$ of them agreed that the teacher was able to help them study English; $50 \%$ of them agreed that the conditions in which they can study English well; $40 \%$ of them agreed that the reason they did not feel like studying English; a half of them (52.5\%) agreed that they were able to motivate themselves when they did not feel like studying English.

\subsubsection{Political-philosophical Dimension}

The sub-dimension of group autonomy showed that the majority of the participants answered that they realized the goals of the English classes they were taking, knew their teacher's expectation towards them in the classroom, and they also agreed that students should do the instructions of their teacher. The findings of individual autonomy sub-dimension showed that the students agreed that they were allowed to tell the teacher what they wanted to study $(57.5 \%)$; make decisions about their learning (65\%); determine the learning materials (45\%); and determine their learning goals (65\%). Besides, 55\% of them confidently answered that they have the capability to determine learning resources when they have complete freedom to do so.; more than half of the students $(70 \%)$ confirmed that they have the ability in determining their learning objectives if given the freedom to do so. Furthermore, the results of the freedom sub-dimension showed that $62.5 \%, 67.5 \%$, and $57.5 \%$ of participants agreed that teachers and students should negotiate about the objectives of learning English, plans and materials for learning English, and topics discussed in learning in the classroom, respectively. 


\subsubsection{Sociocultural Dimension}

Furthermore, the results of the social-interactive sub-dimension showed that the students wanted the teacher to explain everything they did not understand (85\%); to tell them the habit of learning English (67.5\%); to tell them how to study English (62.5\%); and to give learning materials (60\%). Moreover, $97.5 \%$ of them wanted to ask their friends for advice about their English learning; $92.5 \%$ of them wanted to know how other students learned English; $90.0 \%$ of them sometimes compared themselves with other students; $65 \%$ of them stated they felt worried if they were doing not the same with their friends; $75 \%$ of them stated that they sometimes follow what their peers are doing into their learning. Surprisingly, $100 \%$ of the participants agreed that students were able to help each other learn English; 97.5\% of them agreed that studying English with other students was useful; similar to the previous one, $97.5 \%$ of them stated that they learned many things when they studied English with their friends.

Regarding the cultural sub-dimension, $72.5 \%$ of Indonesian students agreed that students in western countries have a high initiative in their learning; $70 \%$ of them agreed that students in western countries tend to make conversation actively during class.; more than half of the participants $(80 \%)$ agreed that Western students are expected to take the initiative in studying. Findings of Indonesian culture reflected that only a minority of the participants (25\%) agreed that Indonesian students tend to take the initiative. In terms of the ability for autonomous learning, $45 \%$ of Indonesian students agreed that they can learn autonomously. Meanwhile, in terms of their experience of autonomous learning, $45 \%$ of Indonesian students agreed that they have the experience of learning autonomously.

\subsection{Qualitative Findings}

After conducting interview with the students, the coding process is done. The selected excerpts were coded and analyzed thematically and then categorized into themes and sub-themes. $\mathrm{Sn}$ is attached at the end of every excerpt, where $\mathrm{n}$ signifies the interviewee.

Table 2: The details of qualitative findings

\begin{tabular}{|l|l|l|}
\hline \multicolumn{1}{|c|}{ Theme } & \multicolumn{1}{|c|}{ Sub-themes } & \multicolumn{1}{c|}{ Selected excerpts } \\
\hline $\begin{array}{l}\text { Students' } \\
\text { conception of } \\
\text { learner } \\
\text { autonomy }\end{array}$ & $\begin{array}{l}\text { Independent learning. } \\
\text { Learning independently } \\
\text { outside the classroom } \\
\text { minus the assistance of the } \\
\text { teacher. }\end{array}$ & $\begin{array}{l}\text { In my opinion, learner autonomy is } \\
\text { independent learning without the help } \\
\text { of lecturers. Learner autonomy makes } \\
\text { learners responsible for their learning. } \\
\text { (S1) }\end{array}$ \\
$\begin{array}{l}\text { Independent learning with } \\
\text { the teacher's assistance or } \\
\text { friends collaboratively. } \\
\text { Students should take } \\
\text { charge of the process of } \\
\text { their learning. }\end{array}$ & $\begin{array}{l}\text { Learner autonomy is independent } \\
\text { learning by finding out what is needed } \\
\text { or what will be studied on the internet } \\
\text { or reading books, but it still needs } \\
\text { guidance from lecturers, friends, and } \\
\text { parents. (S3) } \\
\text { I think that independent learning is }\end{array}$ \\
\hline
\end{tabular}




\begin{tabular}{|c|c|c|}
\hline & $\begin{array}{l}\text { Student's self-awareness } \\
\text { and self-initiated to learn } \\
\text { outside the classroom in } \\
\text { order to find ways of } \\
\text { learning and collaborate } \\
\text { with others. } \\
\text { Learning English anywhere } \\
\text { and anytime. }\end{array}$ & $\begin{array}{l}\text { not always alone. It can be shared } \\
\text { with friends. So, the students have the } \\
\text { initiative to learn collaboratively with } \\
\text { friends. (S6) } \\
\text { Learner autonomy means independent } \\
\text { learning in which the students take full } \\
\text { responsibility for the process of } \\
\text { learning. (S14) } \\
\text { We as students do not only depend on } \\
\text { the material or instructions given by } \\
\text { the lecturer. We can take the initiative } \\
\text { on our own to find and learn other } \\
\text { material by ourselves. (S14) } \\
\text { Students can learn from the internet } \\
\text { because there are so many learning } \\
\text { resources on the internet. (S7) }\end{array}$ \\
\hline $\begin{array}{l}\text { The } \\
\text { advantages of } \\
\text { learner } \\
\text { autonomy }\end{array}$ & $\begin{array}{l}\text { Improving students' } \\
\text { English skills } \\
\text { Improving their } \\
\text { weaknesses and to develop } \\
\text { their potentials } \\
\text { Learning can be more } \\
\text { creative and innovative } \\
\text { Developing students' } \\
\text { knowledge. } \\
\text { Compensating for limited } \\
\text { time and learning material } \\
\text { in the classroom } \\
\text { Learning can be more } \\
\text { personalized }\end{array}$ & $\begin{array}{l}\text { In learning English, we learn speaking, } \\
\text { listening, writing and reading. We } \\
\text { have to practice them to be familiar. } \\
\text { Thus, we must find the material by } \\
\text { ourselves. For example, I watch } \\
\text { English films with subtitles. It teaches } \\
\text { me listening and reading. By watching } \\
\text { English films, I automatically learn } \\
\text { independently. That is one of the } \\
\text { advantages of learner autonomy. (S12) } \\
\text { In my point of view, learner autonomy } \\
\text { plays an important role. Learning in } \\
\text { the classroom is limited. Learning } \\
\text { independently outside the class can } \\
\text { give a deeper knowledge of the } \\
\text { subject. (S1) } \\
\text { Learner autonomy is important } \\
\text { because when we learn independently } \\
\text { and search for learning material by } \\
\text { ourselves, we can understand it well. } \\
\text { (S8) }\end{array}$ \\
\hline $\begin{array}{l}\text { The } \\
\text { undergraduate } \\
\text { students' } \\
\text { autonomy } \\
\text { level }\end{array}$ & $\begin{array}{l}\text { Students were not fully } \\
\text { autonomous in learning } \\
\text { English and confidently } \\
\text { stated that they wanted to } \\
\text { be more autonomous. }\end{array}$ & $\begin{array}{l}\text { I feel that I am still far from } \\
\text { autonomous. Maybe I am at level } \\
\text { average. (S7) } \\
\text { I feel I was not a fully autonomous } \\
\text { learner because I still need guidance to } \\
\text { study. But I am able to learn new } \\
\text { words and phrases through watching } \\
\text { a lot of TV shows or movies, listening } \\
\text { to the song, and reading books. (S11) } \\
\text { Yes, I have loved to learn } \\
\text { independently since elementary school }\end{array}$ \\
\hline
\end{tabular}




\begin{tabular}{|c|c|c|}
\hline & & $\begin{array}{l}\text { to find out what I wanted to know in } \\
\text { English. I learn independently at home } \\
\text { and sometimes study together with } \\
\text { my friend at home. (S14) } \\
\text { Yes, I want to be a more autonomous } \\
\text { learner. I could not always rely on the } \\
\text { lecturer. (S12) }\end{array}$ \\
\hline $\begin{array}{l}\text { Students' } \\
\text { practices of } \\
\text { learner } \\
\text { autonomy }\end{array}$ & $\begin{array}{l}\text { The majority of students } \\
\text { had set their learning goals } \\
\text { both for the short and long } \\
\text { term goals. } \\
\text { They had set their learning } \\
\text { goals in the earlier first } \\
\text { semester and after goat all } \\
\text { the score } \\
\text { Students made a study plan } \\
\text { in learning English } \\
\text { They revised their study } \\
\text { plan when it did not work } \\
\text { well. }\end{array}$ & $\begin{array}{l}\text { Yes, I have set my goals. I want to be } \\
\text { able to speak fluently. Furthermore, in } \\
\text { writing, I want to be able to write } \\
\text { properly. (S10) } \\
\text { I want to continue my master's degree } \\
\text { abroad (S14). } \\
\text { Yes, I set my goals in every early } \\
\text { semester (S6). } \\
\text { I set the goals at the end of the } \\
\text { semester (S5). } \\
\text { I make a study plan to face a quiz, } \\
\text { progress test or post-test (S14). } \\
\text { I have study plans at the beginning of } \\
\text { the semester. Unfortunately, they } \\
\text { didn't run well, so I have to rearrange } \\
\text { the planning (S1). }\end{array}$ \\
\hline
\end{tabular}

Table 2 presents the results of the interview data analysis. These include four themes: 1) students' conception of learner autonomy; 2) the advantages of learner autonomy; 3) the undergraduate students' autonomy level; and 4) students' practices of learner autonomy. The results suggested that the students acknowledge the concept of learner autonomy as independent learning with or without others help. The students in the present study agreed that learner autonomy could improve their English skills. They also claimed that they had set their learning goals and made study plans. Despite the fact they have some skills of learner autonomy, they confirmed that they were not totally autonomous in learning English.

\section{Discussion}

The quantitative findings revealed that the undergraduate students' autonomy in English language learning was at a mediate level. For technical dimension, long-term goal and the ability to create opportunities to learn contributed to the students' level autonomy. Setting goals made learners more motivated, autonomous, and self-regulated. The psychological dimension obtained the highest score. It implies that undergraduate students have intrinsic and extrinsic motivation in learning English. They also pay attention to their cognitive process and they can control their affective in the learning process. The political- 
philosophical dimension shows the necessity of the negotiation process between teachers and students on the goals in learning and the freedom to decide the learning content and activities. Related to the sociocultural dimension, the most important point was collaborative learning. Students develop their autonomy through social interactions with their friends. It suggests that social interactions are crucial to constructing learner autonomy.

The findings of this research are in line with Iamudom and Tangkiengsirisin (2020), in which Thai EFL students' autonomy was at a high level. They used several strategies in learning, such as compensation, metacognitive, and cognitive strategies. However, this finding differs from Cirocki et al. (2019) and Fauzi et al. (2020) wherein Indonesian students seemed not ready to be autonomous learners. They argued that motivation of their participants in learning English was fairly low, the students were still accustomed to the teacher-centered learning approach, and they had misconceptions of learner autonomy. In the current research, the motivational sub-dimension showed the highest score. Moreover, the interview findings explained that the students have intrinsic and extrinsic motivation in learning English and they like studying it. Besides, their motivation is related to their forthcoming wishes, such as to be a professional English teacher, study and work overseas, and get a good job. Oxford (2015) argued that autonomous learners in psychological perspectives have intrinsic motivation in learning. In this study and in addition to having intrinsic motivation, the students also have extrinsic motivation. Their extrinsic motivation encourages their intrinsic motivation to study hard. Hence, it concludes that intrinsic and extrinsic motivations are equally important for learning, as well as motivation is essential in developing learner autonomy (Jianfeng et al., 2018).

Learner autonomy helps the students to learn independently, control and manage their learning and be effective in learning. The quantitative findings showed that they were able to act as autonomous learners. They can set longterm and short-term goals, make a realistic study plan for learning English, and use some metacognitive skills. All these skills are needed by undergraduate students to make them effective in learning (Lengkanawati, 2017). Thus, students who have metacognitive strategies are effective learners or are also categorized as autonomous learners.

The qualitative findings revealed that although most students claimed that they are autonomous learners, they sometimes still need motivation, direction, and guidance from the teacher to practice autonomous learning outside the classroom. They need their teachers' assistance to build up their self-confidence and capability to perform autonomous learning. This reflects on the important part of the teacher to guide and assist the students to gain sufficient knowledge of independent learning out of the classroom. It can be said that the teacher's presence in the process of developing autonomy is crucial (Swatevacharkul \& Boonma, 2021). 
Surprisingly, the findings from the interview showed that the undergraduate students generally have the basic conception of autonomy in language learning as learning independently outside the classroom with teachers' help or working together with others. Learner autonomy cannot be defined as learning without a teacher (Lengkanawati, 2017). Students still need teachers' support on their learning process. Learner autonomy is also defined as independent learning in which the students take full responsibility for the process of learning, and take initiative to find and learn other material. Besides, learner autonomy is students' awareness to deepen their knowledge and have learning goals. It has been concluded that the undergraduate students have background knowledge about learner autonomy.

Moreover, the findings showed the students were not too dependent on their teacher in learning. They could manage their own learning in the circumstances where they study independently. For example, they could learn English independently in the library or at home, and on the internet. In addition, the students also could study English with other students. They enjoyed learning collaboratively with their friends because they were able to learn from their friends. They also confidently said working together with friends their autonomy could be improved. In other words, the schooling system has succeeded to promote learner autonomy to create autonomous learners who are willing to take control of their learning or some aspects of learning. The recent curriculum in Indonesia demanded teachers to shift their instruction from focus on teacher to learner to respond to the industrial revolution and the disruption. It makes learner autonomy crucial to be promoted in the process of teaching and learning. Moreover, learner autonomy could help learners in learning and prepare them for lifelong learning (Tran \& Duong, 2018). It emphasized that the teachers should take an important part in developing a conducive learning atmosphere to promote autonomous learning. Besides, the teacher needs to alter students' viewpoint about the traditional role of the teachers and the learners in the classroom, assist students to find out their learning styles, select the appropriate learning strategies, and know the advantages of autonomous learning.

The findings showed that undergraduate students were allowed to decide the learning process, such as deciding the materials and activities for learning with the teacher's approval. It explains that the teacher is needed as a partner in negotiating the learning process (Swatevacharkul \& Boonma, 2021). Negotiation in the learning process helps students in controlling their learning. Besides, this also informs the importance of teachers to nourish student autonomy. In addition, they agreed that the teacher has the authority to assist, guide, and support students to do some aspects of learning management. Therefore, these results suggest that teachers must involve their students in the decision-making process, and encourage students to set up learning goals based on the evaluation (Çakici, 2015).

Learning autonomously gives students some benefits, such as improving their English skills, developing their potential, increasing their knowledge, and 
compensating for a limited time in the classroom and inadequate learning material. In addition, learner autonomy makes students learn more, personalize their learning, and promote creativity. According to Cotterall (1995a), a teacher is not always there to assist students. Therefore, learners should have the capability to learn independently in learning the language. These findings also confirmed the literature regarding the benefits of learner autonomy. Dam (2008) suggested that learning the language can be implemented well and personalized if students are responsible for their learning.

\section{Conclusion}

The findings showed the Indonesian undergraduate students' learner autonomy in terms of technical, psychological, political-philosophical, and socio-cultural dimensions was categorized as mediate level autonomy. The technical dimension indicated that students can set goals, make a study plan, reflect on, monitor, and evaluate the learning process. The psychological dimension showed high motivation. Specifically, the undergraduate students have intrinsic and extrinsic motivation for autonomous learning, thus they have the ability to control their affective in learning English and employed metacognitive skills. The political-philosophical dimensions revealed that the students were allowed to make a decision in their learning based on the results of the negotiation with teachers. In addition, they perceived that teachers have the authority to help and guide students in learning. The results of social-interactive sub-dimensions revealed that the students prefer to work collaboratively with their peers to reach the learning goal. However, they still need the teacher's contribution to developing learner autonomy. Dealing with cultural sub-dimension, they agreed that learner autonomy is also appropriate for Indonesian learners. Furthermore, the study concluded that the undergraduate students are autonomous learners because they have sufficient knowledge about the concepts and the advantages of learner autonomy that make them ready to act autonomously and have autonomous skills. This study suggests that the teachers need to continuously increase the students' knowledge of the significance of learner autonomy in language learning and consistently implementing this approach in teaching. A limitation of this research is that the participants only involved EFL learners from a university in Indonesia. It is suggested that the future research should cover a larger participants from many universities to get more comprehensive information of the learners' level of autonomy.

\section{References}

Abdel Razeq, A. A. (2014). University EFL learners' perceptions of their autonomous learning responsibilities and abilities. RELC Journal, 45(3), 321-336. https://doi.org/10.1177/0033688214547035

Agustina, D. (2017). Teachers' understanding of learner autonomy in Indonesian context: Findings from high school and their implications. LLT Journal: A Journal on Language and Language Teaching, 20(2), 127-132. https:/ / doi.org/10.24071/1lt.2017.200206

Alrabai, F. (2017). Exploring the unknown: The autonomy of Saudi EFL learners. English Language Teaching, 10(5), 222. https:/ / doi.org/10.5539/elt.v10n5p222

Andina, D. M., Cahyono, B. Y., \& Widiati, U. (2020). How English foreign language students' autonomy and digital competence relate to their writing achievement. 
Tadris: Jurnal Keguruan Dan Ilmu Tarbiyah, 5(1), 77-86. https://doi.org/10.24042/tadris.v5i1.5760

Benson, P. (1997). The philosophy and politics of learner autonomy. In P. Benson \& P. Voller (Eds.), Autonomy and independence in language learning (pp. 18-34). Longman. https://doi.org/10.4324/9781315842172

Benson, P. (2011). What's new in autonomy. The Language Teacher, 35(4), 15-18. https://jalt-publications.org/files/pdf-article/plen3.pdf

Benson, P. (2013). Teaching and researching: Autonomy in language learning (2nd ed.). Routledge. https://doi.org/10.4324/9781315833767

Benson, P., \& Voller, P. (2014). Autonomy and independence in language learning (1st ed.). Routledge. https://doi.org/10.4324/9781315842172

Borg, S., \& Alshumaimeri, Y. (2019). Language learner autonomy in a tertiary context: Teachers' beliefs and practices. Language Teaching Research, 23(1), 9-38. https://doi.org/10.1177\%2F1362168817725759

Breen, P., \& Mann, S. (1997). Shooting around at the sun: Perspectives on a pedagogy for autonomy in Benson. In P. Benson \& P. Voller (Eds.), Autonomy and independence in language learning (pp. 132-149). Longman. https://doi.org/10.4324/9781315842172

Çakici, D. (2015). Autonomy in language teaching and learning process. İnönü Üniversitesi Eğitim Fakültesi Dergisi, https://doi.org/10.17679/iuefd.16168538

Cirocki, A., Anam, S., \& Retnaningdyah, P. (2019). Readiness for autonomy in English language learning: The case of Indonesian high school students. Iranian Journal of Language Teaching Research, 7(2), 1-18. https://doi.org/10.30466/ijltr.2019.120695

Cotterall, S. (1995a). Developing a course strategy for learner autonomy. ELT Journal, 49(3), 219-227. https://doi.org/10.1093/elt/49.3.219

Cotterall, S. (1995b). Readiness for autonomy: Investigating learner beliefs. System, 23(2), 195-205. https://doi.org/10.1016/0346-251X(95)00008-8

Creswell, J. W., \& Clark, V. L. P. (2017). Designing and conducting mixed methods research. Sage publications.

Dam, L. (2008). In-service teacher education for learner autonomy. IATEFL Learner Autonomy SIG, 11(6), 20-28.

Dickinson, L. (1993). Talking shop: Aspects of autonomous learning. ELT Journal, 47(4), 330-336. https://doi.org/10.1093/elt/47.4.330

Dörnyei, Z. (2007). Research methods in applied linguistics. Oxford university press.

Fauzi, C., Basikin, D. S., \& Kassymova, G. (2020). Exploring EFL student teachers readiness and gender differences of learner autonomy. Bulletin of National Academy of Sciences of the Republic of Kazakhstan ,1 (383), 288-299. . https://doi.org/https://doi.org/10.32014/2020.2518-1467.34

Gleason, N. W. (2018). Singapore's higher education systems in the era of the fourth industrial revolution: Preparing lifelong learners. In N. Gleason (Ed.), Higher education in the era of the fourth industrial revolution (pp. 145-169). Palgrave Macmillan, Singapore. https:// doi.org/10.1007/978-981-13-0194-0_7

Hsu, W.-C., Ling, X., \& Xuelian, X. (2019). An investigation of responsibility and learner autonomy in a Sino-British EAP program in China. Journal of Asia TEFL, 16(1), 220. https://doi.org/DOI:10.18823/asiatefl.2019.16.1.14.220

Iamudom, T., \& Tangkiengsirisin, S. (2020). A comparison study of learner autonomy and language learning strategies among Thai EFL learners. International Journal of Instruction, 13(2), 199-212. https:// doi.org/10.29333/iji.2020.13214a 
Jianfeng, C., Raj, S. G., \& Tan Tjin Ai, J. (2018). The correlations among learning motivation, autonomy and language proficiency in Chinese EFL context. LEARN Journal: Language Education and Acquisition Research Network, 11(1), 1-14. https://so04.tci-thaijo.org/index.php/LEARN/article/view/135861/101464

Khotimah, K., Widiati, U., Mustofa, M., \& Faruq Ubaidillah, M. (2019). Autonomous English learning: Teachers' and students' perceptions. Indonesian Journal of Applied Linguistics, 9(2), 371-381. https://doi.org/10.17509/ijal.v9i2.20234

Khulaifiyah, K., Widati, U., Anugerahwati, M., \& Suryati, N. (2021). Autonomous learning activities: The perceptions of English language students in Indonesia. Pegem Journal of Education and Instruction, 11(3), 34-49. https:// mail.pegegog.net/index.php/pegegog/article/view/1362

Kobayashi, A. (2020). Fostering learner autonomy in an EFL classroom through an action research by adapting extensive listening activities. Language Education $\mathcal{E}$ Technology, 57, 91-120. https://doi.org/10.24539/let.57.0_91

Le Thanh Nguyet, A. N. H. (2019). Teachers' and students' perceptions and practices regarding learner autonomy: An exploratory study at a Viatnamese University in the Mekong Delta. HUE University.

Lengkanawati, N. S. (2017). Learner autonomy in the Indonesian EFL settings. Indonesian Journal of Applied Linguistics, 6(2), 222-231. https://doi.org/10.17509/ijal.v6i2.4847

Lin, L., \& Reinders, H. (2019). Students' and teachers' readiness for autonomy: Beliefs and practices in developing autonomy in the Chinese context. Asia Pacific Education Review, 20(1), 69-89. https://doi.org/10.1007/s12564-018-9564-3

Little, D. (1990). Autonomy in language learning. In A. Swarbrick (Ed.), Teaching modern languages. The Open university.

Little, D., \& Dam, L. (1998). Learner autonomy: What and why? JALT, 22, 7-8.

Littlewood, W. (1996). "Autonomy": An anatomy and a framework. System, 24(4), 427435. https://doi.org/10.1016/S0346-251X(96)00039-5

Littlewood, W. (1999). Defining and developing autonomy in East Asian contexts. Applied Linguistics, 20(1), 71-94. https://doi.org/10.1093/applin/20.1.71

Mardjuki, M. S. (2018). Learner autonomy: Gender-based perception among EFL Indonesian students. Indonesian Journal of EFL and Linguistics, 3(1), 1. https://doi.org/10.21462/ijefll.v3i1.46

Meisani, D. R., \& Rambet, R. D. B. (2017). Teachers' beliefs regarding language learner autonomy and practices of project-based education: A case study of an Indonesian EFL teacher. NOBEL: Journal of Literature and Language Teaching, 8(2), 141-149. https:// doi.org/10.15642/NOBEL.2017.8.2.141-149

Melvina, M, \& Julia, J. (2021). Learner autonomy and English proficiency of Indonesian undergraduate students. Cypriot Journal of Educational Sciences, 16(2), 803-818. https://doi.org/10.18844/cjes.v16i2.5677

Melvina, M., \& Suherdi, D. (2019). Indonesian ELT teachers' beliefs toward language learner autonomy. Paper presented at the Second Conference on Language, Literature, Education, and Culture (ICOLLITE 2018), 239-242. https://doi.org/10.2991/icollite-18.2019.53

Muhammad, M. (2020). Promoting students' autonomy through online learning media in EFL class. International Journal of Higher Education, 9(4), 320-331. https://doi.org/10.5430/ijhe.v9n4p320

Murase, F. (2015). Measuring language learner autonomy: Problems and possibilities. In C.J. Everhard \& L. Murphy (Eds.), Assessment and autonomy in language learning (pp. 35-63). Palgrave Macmillan, London. https://doi.org/10.1057/9781137414380_3 
Myartawan, I. P. N. W., Latief, M. A., \& Suharmanto. (2013). The corelation between learner autonomy and English proficiency of Indonesian EFL college learners. TEFLIN Journal, 24(1), 63-81. https://doi.org/http://dx.doi.org/10.15639/teflinjournal.v24i1/63-81

Mynard, J. (2019). Self-access learning and advising: Promoting language learner autonomy beyond the classroom. In H. Reinders, S. Ryan \& S. Sakammura (Eds.), Innovation in language teaching and learnin. New language learning and teaching envirnments (pp. 185-209).Palgrave Mcmillan, Cham. https://doi.org/10.1007/978-3-030-12567-7_10

Nunan, D. (2003). Nine steps to learner autonomy. Symposium, 2003, 193-204. http://www.su.se/polopoly_fs/1.84007.1333707257!/menu/standard/file/2003 _11_Nunan_eng.pdf

Oxford, R. L. (2003). Toward a more systematic model of L2 learner autonomy. In D .Palfreyman \& R.C. Smith (Eds.), Learner autonomy across cultures (pp. 75-91). Palgrave Macmillan, London. https://doi.org/10.1057/9780230504684_5

Oxford, R. L. (2008). Hero with a thousand faces: Learner autonomy, learning strategies and learning tactics in independent language learning. In S. Hurd \& T. Lewis (Eds.), Language learning strategies in independent settings ( p. 41). Multilingual Matters Bristol. https://doi.org/10.21832/9781847690999-005

Oxford, R. L. (2015). Expanded perspectives on autonomous learners. Innovation in Language Learning and Teaching, 9(1), 58-71. https://doi.org/https://doi.org/10.1080/17501229.2014.995765

Palfreyman, D. (2003). Introduction: Culture and learner autonomy. In D. Palfreyman \& R. C. Smith (Eds.), Learner autonomy across cultures (pp. 1-19). Palgrave Macmillan, London. https://doi.org/10.1057/9780230504684_1

Ramadhiyah, S., \& Lengkanawati, N. S. (2019). Exploring EFL learner autonomy in the 2013 curriculum implementation. Indonesian Journal of Applied Linguistics, 9(1), 231-240. https://doi.org/10.17509/ijal.v9i1.15626

Sönmez, G. (2016). How ready are your students for autonomous language learning. Turkish Online Journal of English Language Teaching (TOJELT), 1(3), 126-134.

Suherdi, D. (2019). Teaching English in the industry 4.0 and disruption era: Early lessons from the implementation of SMELT I 4.0 DE in a senior high lab school class. Indonesian Journal of Applied Linguistics, 9(1), 67-75. https:// doi.org/10.17509/ijal.v9i1.16418

Swatevacharkul, R., \& Boonma, N. (2021). Learner autonomy assessment of English language teaching students in an international program in Thailand. Indonesian $\begin{array}{llll}\text { Journal of Applied } & \text { 2inguistics, 10(3), 749-759. }\end{array}$ https://doi.org/10.17509/ijal.v10i3.31764

Tayjasanant, C., \& Suraratdecha, S. (2016). Thai EFL teachers and learners' beliefs and readiness for autonomous learning. 3L: Language, Linguistics, Literature $®$, 22(3). https://doi.org/10.17576/3L-2016-2203-11

Tran, T. Q., \& Duong, T. M. (2018). EFL learners' perceptions of factors influencing learner autonomy development. Kasetsart Journal of Social Sciences, 1-6. https://doi.org/10.1016/j.kjss.2018.02.009

Vaske, J. J., Beaman, J., \& Sponarski, C. C. (2017). Rethinking internal consistency in Cronbach's alpha. Leisure Sciences, 39(2), 163-173. https://doi.org/10.1080/01490400.2015.1127189

Wenden, A. L. (1998). Metacognitive knowledge and language learning1. Applied Linguistics, 19(4), 515-537. https://doi.org/10.1093/applin/19.4.515 


\section{Appendices}

\section{Appendix 1. Technical Dimension}

\begin{tabular}{|c|c|c|c|c|c|c|c|c|c|c|}
\hline \multirow[t]{2}{*}{ No } & \multirow[t]{2}{*}{ Technical } & \multicolumn{2}{|c|}{ Never } & \multicolumn{2}{|c|}{ Rarely } & \multicolumn{2}{|c|}{ Frequently } & \multicolumn{2}{|c|}{ Always } & \multirow{2}{*}{$\begin{array}{c}\text { Index } \\
\text { score } \\
\%\end{array}$} \\
\hline & & $\mathbf{F}$ & $\%$ & f & $\%$ & f & $\%$ & f & $\%$ & \\
\hline 1 & $\begin{array}{l}\text { I set long-term goals in } \\
\text { learning English. }\end{array}$ & & 0 & 13 & 32.5 & 18 & 45.0 & 9 & 22.5 & 73 \\
\hline 2 & $\begin{array}{l}\text { I make long-term plans for } \\
\text { studying English. }\end{array}$ & & 0 & 15 & 37.5 & 18 & 45.0 & 7 & 17.5 & 70 \\
\hline 3 & $\begin{array}{l}\text { I set goals for the day before I } \\
\text { start studying English. }\end{array}$ & 3 & 7.5 & 19 & 47.5 & 15 & 37.5 & 3 & 7.5 & 61 \\
\hline 4 & $\begin{array}{l}\text { I make study plans for the day } \\
\text { before I start studying English. }\end{array}$ & 3 & 7.5 & 16 & 40.0 & 19 & 47.5 & 2 & 5.0 & 63 \\
\hline 5 & $\begin{array}{l}\text { I make study plans that match } \\
\text { my goals in learning English. }\end{array}$ & 1 & 2.5 & 17 & 42.5 & 20 & 50.0 & 2 & 5.0 & 64 \\
\hline 6 & $\begin{array}{l}\text { I make realistic plans for } \\
\text { studying English. }\end{array}$ & 1 & 2.5 & 8 & 20.0 & 20 & 50.0 & 11 & 27.5 & 76 \\
\hline 7 & $\begin{array}{l}\text { I revise my English study } \\
\text { plans if they don't work well. }\end{array}$ & 1 & 2.5 & 11 & 27.5 & 16 & 40.0 & 12 & 30.0 & 74 \\
\hline 8 & $\begin{array}{l}\text { If I have a limited amount of } \\
\text { time available for study, I } \\
\text { decide in what order the things } \\
\text { need to be done. }\end{array}$ & & 0 & 2 & 5.0 & 15 & 37.5 & 23 & 57.5 & 88 \\
\hline 9 & $\begin{array}{l}\text { I reflect upon how I studied } \\
\text { after I finish studying English } \\
\text { for the day. }\end{array}$ & 1 & 2.5 & 17 & 42.5 & 15 & 37.5 & 7 & 17.5 & 68 \\
\hline 10 & $\begin{array}{l}\text { I try to create opportunities to } \\
\text { use English outside the } \\
\text { classroom. }\end{array}$ & & 0 & 11 & 27.5 & 16 & 40.0 & 13 & 32.5 & 76 \\
\hline 11 & $\begin{array}{l}\text { I try to create the conditions } \\
\text { under which I can study } \\
\text { English best. }\end{array}$ & 1 & 2.5 & 4 & 10 & 24 & 60 & 11 & 27.5 & 78 \\
\hline 12 & $\begin{array}{l}\text { I reflect upon what I learned } \\
\text { after I finish studying English } \\
\text { for the day. }\end{array}$ & & 0 & 15 & 37.5 & 19 & 47.5 & 6 & 15.0 & 69 \\
\hline 13 & $\begin{array}{l}\text { I evaluate the improvement in } \\
\text { my ability to use English } \\
\text { effectively. }\end{array}$ & 2 & 5.0 & 8 & 20.0 & 20 & 50.0 & 10 & 25.0 & 74 \\
\hline 14 & $\begin{array}{l}\text { I assess how much of my goal } \\
\text { I have achieved. }\end{array}$ & 4 & 10 & 13 & 32.5 & 16 & 40 & 7 & 17.5 & 66 \\
\hline 15 & $\begin{array}{l}\text { I assess the effectiveness of } \\
\text { my English study plans. }\end{array}$ & 3 & 7.5 & 18 & 45.0 & 15 & 37.5 & 4 & 10 & 63 \\
\hline 16 & $\begin{array}{l}\text { I take notes about how much } \\
\text { time I spent on my English } \\
\text { study. }\end{array}$ & 19 & 47.5 & 16 & 40.0 & 4 & 10.0 & 1 & 2.5 & 42 \\
\hline 17 & $\begin{array}{l}\text { I keep records of what kind of } \\
\text { methods I used for my English } \\
\text { study. }\end{array}$ & 10 & 25.0 & 21 & 52.5 & 7 & 17.5 & 2 & 5.0 & 51 \\
\hline 18 & $\begin{array}{l}\text { I write down what kinds of } \\
\text { materials I used for my } \\
\text { English study. }\end{array}$ & 6 & 15.0 & 12 & 30.0 & 16 & 40.0 & 6 & 15.0 & 64 \\
\hline 19 & $\begin{array}{l}\text { I keep records of what I } \\
\text { learned from my English } \\
\text { study. }\end{array}$ & 2 & 5.0 & 8 & 20.0 & 22 & 55.0 & 8 & 20.0 & 73 \\
\hline 20 & $\begin{array}{l}\text { I take notes of my feelings } \\
\text { while I am studying English. }\end{array}$ & 21 & 52.5 & 10 & 25.0 & 6 & 15.0 & 3 & 7.5 & 44 \\
\hline 21 & $\begin{array}{l}\text { I am able to study English } \\
\text { without teachers in the } \\
\text { campus library or on the } \\
\text { internet provided by the } \\
\text { library. }\end{array}$ & 1 & 2.5 & 11 & 27.5 & 21 & 52.5 & 7 & 17.5 & 71 \\
\hline 22 & $\begin{array}{l}\text { I attend a self-study center } \\
\text { to develop my English } \\
\text { skills. }\end{array}$ & 11 & 27.5 & 17 & 42.5 & 11 & 27.5 & 1 & 2.5 & 51 \\
\hline
\end{tabular}


$\begin{array}{lllllllllll}23 & \text { I join English club where I } & 17 & 42.5 & 13 & 32.5 & 7 & 17.5 & 3 & 7.5 & 48\end{array}$ can practice my English

\section{Appendix 2. Psychological Dimension}

\begin{tabular}{|c|c|c|c|c|c|c|c|c|c|c|}
\hline \multirow[t]{2}{*}{ No } & \multirow[t]{2}{*}{ Psychological } & \multicolumn{2}{|c|}{$\begin{array}{l}\text { Strongly } \\
\text { Disagree }\end{array}$} & \multicolumn{2}{|c|}{ Disagree } & \multicolumn{2}{|c|}{ Agree } & \multicolumn{2}{|c|}{$\begin{array}{l}\text { Strongly } \\
\text { agree }\end{array}$} & \multirow{2}{*}{$\begin{array}{l}\text { Inde } \\
\mathbf{x} \\
\text { score } \\
\%\end{array}$} \\
\hline & & $\mathbf{f}$ & $\%$ & f & $\%$ & f & $\%$ & $\mathbf{F}$ & $\%$ & \\
\hline 38 & $\begin{array}{l}\text { I know what I need to } \\
\text { study to improve my } \\
\text { English. }\end{array}$ & & 0 & 4 & 10.0 & 26 & 65.0 & 10 & 25.0 & 79 \\
\hline 39 & $\begin{array}{l}\text { I know what I am good } \\
\text { at in learning English. } \\
\text { (e.g., 'I am good at } \\
\text { memorizing } \\
\text { vocabulary.') }\end{array}$ & & 0 & 5 & 12.5 & 23 & 57.5 & 12 & 30.0 & 79 \\
\hline 40 & $\begin{array}{l}\text { If I ask my teacher for } \\
\text { help in learning English, } \\
\text { I know how I want } \\
\text { him/her to help me. }\end{array}$ & & 0 & 10 & 25.0 & 24 & 60.0 & 6 & 15.0 & 73 \\
\hline 41 & $\begin{array}{l}\text { I know the conditions } \\
\text { under which I can study } \\
\text { English best. }\end{array}$ & 2 & 5.0 & 3 & 7.5 & 20 & 50.0 & 15 & 37.5 & 80 \\
\hline 42 & $\begin{array}{l}\text { If I don't feel like } \\
\text { studying English, I } \\
\text { know the reason. }\end{array}$ & 2 & 5.0 & 7 & 17.5 & 16 & 40.0 & 15 & 37.5 & 78 \\
\hline 43 & $\begin{array}{l}\text { If I don't feel like } \\
\text { studying English, I } \\
\text { know how I can } \\
\text { motivate myself. }\end{array}$ & & 0 & 9 & 22.5 & 21 & 52.5 & 10 & 25.0 & 76 \\
\hline 44 & $\begin{array}{l}\text { I want to study overseas } \\
\text { in the future. }\end{array}$ & & 0 & 2 & 5.0 & 4 & 10.0 & 34 & 85.0 & 95 \\
\hline 45 & $\begin{array}{l}\text { I want to work overseas } \\
\text { in the future. }\end{array}$ & 2 & 5.0 & 1 & 2.5 & 11 & 27.5 & 26 & 65.0 & 88 \\
\hline 46 & $\begin{array}{l}\text { I want to get a job } \\
\text { where I use English in } \\
\text { the future. }\end{array}$ & & 0 & & 0 & 10 & 25.0 & 30 & 75.0 & 94 \\
\hline 47 & $\begin{array}{l}\text { I like the English } \\
\text { language. }\end{array}$ & 1 & 2.5 & & 0 & 14 & 35.0 & 25 & 62.5 & 89 \\
\hline 48 & I like studying English. & & 0 & 1 & 2.5 & 20 & 50.0 & 19 & 47.5 & 86 \\
\hline 49 & $\begin{array}{l}\text { I give a higher priority } \\
\text { to studying English than } \\
\text { studying other academic } \\
\text { subjects. }\end{array}$ & 1 & 2.5 & 9 & 22.5 & 15 & 37.5 & 15 & 37.5 & 78 \\
\hline 50 & $\begin{array}{l}\text { The reason why I study } \\
\text { English is to pass } \\
\text { English qualifying } \\
\text { exams (e.g.,TOEIC, } \\
\text { TOEFL) }\end{array}$ & 2 & 5.0 & 17 & 42.5 & 14 & 35.0 & 7 & 17.5 & 66 \\
\hline 51 & $\begin{array}{l}\text { It is because I think } \\
\text { English skills will help } \\
\text { me get a job. }\end{array}$ & & 0 & & 0 & 12 & 30.0 & 28 & 70.0 & 93 \\
\hline
\end{tabular}




\section{Appendix 3. Political Philosophical Dimension}

\begin{tabular}{|c|c|c|c|c|c|c|c|c|c|c|}
\hline \multirow[t]{2}{*}{ No } & \multirow[t]{2}{*}{ Political } & \multicolumn{2}{|c|}{$\begin{array}{l}\text { Strongly } \\
\text { Disagree }\end{array}$} & \multicolumn{2}{|c|}{ Disagree } & \multicolumn{2}{|c|}{ Agree } & \multicolumn{2}{|c|}{$\begin{array}{l}\text { Strongly } \\
\text { agree }\end{array}$} & \multirow{2}{*}{$\begin{array}{c}\begin{array}{c}\text { Index } \\
\text { score }\end{array} \\
\%\end{array}$} \\
\hline & & f & $\%$ & f & $\%$ & f & $\%$ & f & $\%$ & \\
\hline 52 & $\begin{array}{l}\text { All university } \\
\text { regulations must be } \\
\text { obeyed. }\end{array}$ & & 0 & 5 & 12.5 & 25 & 62.5 & 10 & 25.0 & 78 \\
\hline 53 & $\begin{array}{l}\text { We should fulfill the } \\
\text { expectations of our } \\
\text { society. }\end{array}$ & 3 & 7.5 & 13 & 32.5 & 15 & 37.5 & 9 & 22.5 & 69 \\
\hline 54 & $\begin{array}{l}\text { I am aware of the } \\
\text { Indonesian } \\
\text { government's policy } \\
\text { on English language } \\
\text { education. }\end{array}$ & 3 & 7.5 & 17 & 42.5 & 19 & 47.5 & 1 & 2.5 & 61 \\
\hline 55 & $\begin{array}{l}\text { I am aware of the goals } \\
\text { of the English class } \\
\text { (es) I am taking. }\end{array}$ & & 0 & & 0 & 31 & 77.5 & 9 & 22.5 & 81 \\
\hline 56 & $\begin{array}{l}\text { I know what my } \\
\text { teacher expects me to } \\
\text { do in the classroom. }\end{array}$ & & 0 & 2 & 5.0 & 29 & 72.5 & 9 & 22.5 & 79 \\
\hline 57 & $\begin{array}{l}\text { Students should always } \\
\text { follow their teacher's } \\
\text { instructions. }\end{array}$ & 2 & 5.0 & 10 & 25.0 & 21 & 52.5 & 7 & 17.5 & 71 \\
\hline 58 & $\begin{array}{l}\text { What a teacher says is } \\
\text { always correct. }\end{array}$ & 8 & 20.0 & 31 & 77.5 & 1 & 2.5 & & 0 & 46 \\
\hline 59 & $\begin{array}{l}\text { A teacher should know } \\
\text { everything about the } \\
\text { subject he/she teaches. }\end{array}$ & 1 & 2.5 & 3 & 7.5 & 20 & 50.0 & 16 & 40.0 & 82 \\
\hline 60 & $\begin{array}{l}\text { I have the right to } \\
\text { freely tell the teacher } \\
\text { what I want to learn in } \\
\text { listening/ speaking/ } \\
\text { reading/ writing for } \\
\text { academic purposes } \\
\text { class. }\end{array}$ & 1 & 2.5 & 12 & 30.0 & 23 & 57.5 & 4 & 10.0 & 69 \\
\hline 61 & $\begin{array}{l}\text { I have the right to } \\
\text { freely make decisions } \\
\text { about my own learning } \\
\text { in listening/ speaking/ } \\
\text { reading/ writing for } \\
\text { academic purposes } \\
\text { class. }\end{array}$ & 1 & 2.5 & 8 & 20.0 & 26 & 65.0 & 5 & 12.5 & 72 \\
\hline 62 & $\begin{array}{l}\text { I have the right to } \\
\text { freely decide the } \\
\text { materials for studying } \\
\text { English in listening/ } \\
\text { speaking/ reading/ } \\
\text { writing for academic } \\
\text { purposes class. }\end{array}$ & 2 & 5.0 & 16 & 40.0 & 18 & 45.0 & 4 & 10.0 & 65 \\
\hline 63 & $\begin{array}{l}\text { I have the right to } \\
\text { freely decide my own } \\
\text { goals in listening/ } \\
\text { speaking/ reading/ }\end{array}$ & 1 & 2.5 & 5 & 12.5 & 26 & 65.0 & 8 & 20.0 & 76 \\
\hline
\end{tabular}


writing for academic

purposes class.

64 I am able to decide the $\quad \begin{array}{lllllllll}0 & 9 & 22.5 & 22 & 55.0 & 9 & 22.5 & 75\end{array}$

materials for studying

English if given the

freedom to do so.

\begin{tabular}{llllllllll}
\hline 65 & $\begin{array}{l}\text { I am able to decide my } \\
\text { own goals in learning } \\
\begin{array}{l}\text { English if given the } \\
\text { freedom to do so. }\end{array} \\
66\end{array}$ \\
$\begin{array}{l}\text { The teacher and } \\
\text { students should } \\
\text { negotiate on the goals } \\
\text { in learning English. }\end{array}$ \\
\hline 67
\end{tabular}

\section{Appendix 4. Sociocultural Dimension}

\begin{tabular}{|c|c|c|c|c|c|c|c|c|c|c|}
\hline \multirow[t]{2}{*}{ No } & \multirow[t]{2}{*}{ Social-culture } & \multicolumn{2}{|c|}{$\begin{array}{l}\text { Strongly } \\
\text { Disagree }\end{array}$} & \multicolumn{2}{|c|}{ Disagree } & \multicolumn{2}{|c|}{ Agree } & \multicolumn{2}{|c|}{$\begin{array}{l}\text { Strongly } \\
\text { agree }\end{array}$} & \multirow{2}{*}{$\begin{array}{c}\text { Index } \\
\text { score } \\
\%\end{array}$} \\
\hline & & $\mathbf{f}$ & $\%$ & $\mathbf{f}$ & $\%$ & $\mathbf{F}$ & $\%$ & f & $\%$ & \\
\hline 70 & $\begin{array}{l}\text { I want my teacher to explain } \\
\text { everything I don't } \\
\text { understand. }\end{array}$ & & 0 & 6 & 15.0 & 20 & 50.0 & 14 & 35.0 & 80 \\
\hline 71 & $\begin{array}{l}\text { I want my teacher to tell me } \\
\text { all I should do to learn } \\
\text { English. }\end{array}$ & & 0 & 13 & 32.5 & 19 & 47.5 & 8 & 20.0 & 72 \\
\hline 72 & $\begin{array}{l}\text { I want my teacher to tell me } \\
\text { how I should study English. }\end{array}$ & 1 & 2.5 & 14 & 35.0 & 16 & 40.0 & 9 & 22.5 & 71 \\
\hline 73 & $\begin{array}{l}\text { I want my teacher to give me } \\
\text { all the materials for studying } \\
\text { English }\end{array}$ & & 0 & 16 & 40.0 & 17 & 42.5 & 7 & 17.5 & 69 \\
\hline 74 & $\begin{array}{l}\text { I sometimes want to ask } \\
\text { other students for advice } \\
\text { about my English learning. }\end{array}$ & & 0 & 1 & 2.5 & 29 & 72.5 & 10 & 25.0 & 81 \\
\hline 75 & $\begin{array}{l}\text { I want to know how other } \\
\text { students are learning } \\
\text { English. }\end{array}$ & & 0 & 3 & 7.5 & 21 & 52.5 & 16 & 40.0 & 83 \\
\hline 76 & $\begin{array}{l}\text { I sometimes compare myself } \\
\text { with other students }\end{array}$ & 2 & 5.0 & 2 & 5.0 & 20 & 50.0 & 16 & 40.0 & 81 \\
\hline 77 & $\begin{array}{l}\text { If I am doing something } \\
\text { different from other students, } \\
\text { I feel worried. }\end{array}$ & 3 & 7.5 & 11 & 27.5 & 14 & 35.0 & 12 & 30.0 & 72 \\
\hline 78 & $\begin{array}{l}\text { I sometimes adopt what } \\
\text { other students are doing into } \\
\text { my own learning. }\end{array}$ & 3 & 7.5 & 7 & 17.5 & 20 & 50.0 & 10 & 25.0 & 73 \\
\hline 79 & $\begin{array}{l}\text { Students can help each other } \\
\text { learn English. }\end{array}$ & & 0 & & 0 & 21 & 52.5 & 19 & 47.5 & 87 \\
\hline 80 & $\begin{array}{l}\text { I find it useful to study } \\
\text { English with other students. }\end{array}$ & & 0 & 1 & 2.5 & 22 & 55.0 & 17 & 42.5 & 85 \\
\hline
\end{tabular}




\begin{tabular}{|c|c|c|c|c|c|c|c|c|c|c|}
\hline 81 & $\begin{array}{l}\text { If I study English with other } \\
\text { students, I also learn from } \\
\text { them. }\end{array}$ & & 0 & 1 & 2.5 & 22 & 55.0 & 17 & 42.5 & 85 \\
\hline 82 & $\begin{array}{l}\text { Western students tend to } \\
\text { take the initiative in their } \\
\text { learning. }\end{array}$ & & 0 & 4 & 10.0 & 29 & 72.5 & 7 & 17.5 & 77 \\
\hline 83 & $\begin{array}{l}\text { Western students tend to } \\
\text { speak out actively during } \\
\text { class. }\end{array}$ & & 0 & 5 & 12.5 & 28 & 70.0 & 7 & 17.5 & 76 \\
\hline 84 & $\begin{array}{l}\text { In Western cultures, students } \\
\text { are expected to take the } \\
\text { initiative in their learning. }\end{array}$ & & 0 & & 0 & 32 & 80.0 & 8 & 20.0 & 80 \\
\hline 85 & $\begin{array}{l}\text { Indonesian students tend to } \\
\text { take the initiative in their } \\
\text { learning. }\end{array}$ & 5 & 12.5 & 23 & 57.5 & 10 & 25.0 & 2 & 5.0 & 56 \\
\hline 86 & $\begin{array}{l}\text { Indonesian students have the } \\
\text { ability to learn } \\
\text { autonomously. }\end{array}$ & 1 & 2.5 & 16 & 40.0 & 18 & 45.0 & 5 & 12.5 & 67 \\
\hline 87 & $\begin{array}{l}\text { Indonesian students have the } \\
\text { experience of learning } \\
\text { autonomously. }\end{array}$ & 3 & 7.5 & 15 & 37.5 & 18 & 45.0 & 4 & 10.0 & 64 \\
\hline
\end{tabular}

